\title{
Cu ナノ粒子を用いた回路形成
}

\section{1.はじめに}

プリンテッド・エレクトロクスは，筐体やフィルムなどの 基材に導電材料を直接回路形成する技術であり, $\mathrm{Ag} や \mathrm{Cu}$ ナノ粒子を含む導電性インクを用いて, 様々なアプリケー

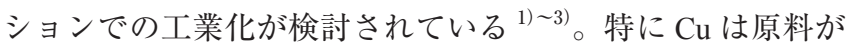
安価でマイグレーション耐性があることから, 工業的な利用 が盛んに検討されているが, $\mathrm{Cu}$ ナノ粒子は非常に活性であり， 室温でも酸化が進み，凝集しやすいことから，低抵抗な皮膜 を形成するためには，焼成方法が重要である。本稿では， $\mathrm{Cu}$ ナノ粒子を用いた回路形成について紹介する。

\section{2. $\mathrm{Cu}$ ナノ粒子の焼成}

$\mathrm{Cu}$ ナノ粒子は，室温大気下で容易に酸化するため，低抵 抗な導体皮膜を得るためには，不活性もしくは還元雲囲気で 焼成する必要がある。バッチ処理可能な筐体や部品上での回 路形成をする場合には，基材の耐熱温度付近で焼成し，導体 回路を形成する。図 1 にスクリーンパッド $(\mathrm{SP})$ 印刷によりガ ラス曲面に直接回路形成したサンプルの外観を示す。スクリー ンパッドは，立体物へ厚膜回路形成が可能であり，ギ酸䨌囲 気で $200{ }^{\circ} \mathrm{C}$ 以上の温度で焼成した $\mathrm{Cu}$ 電極は, $10 \mu \Omega \cdot \mathrm{cm}$ の体 積抵抗率であり，はんだ付けによる部品実装も可能である。

Roll to Roll に適した焼成法として, 光焼成がある。ポリイ ミド基材上に $\mathrm{Cu}$ ナノインクをインクジェット(IJ)印刷し, フラッシュランプで焼成した $\mathrm{Cu}$ 皮膜の膜厚は約 $0.6 \mu \mathrm{m}$, 体 積抵抗率は $4 \mu \Omega \cdot \mathrm{cm}$ であり，基材とテープで剥離しない密 着性がある。光焼成は, フラッシュランプで紫外から赤外ま での幅広い波長を有する光を大気下で約 $1 \mathrm{msec}$. 照射し, $\mathrm{Cu}$ ナノ粒子を焼結する焼成法であり, 膜厚 $5 \mu \mathrm{m}$ 以下の $\mathrm{Cu}$ ナ ノインクの導体化に適している。

$\mathrm{Cu}$ ナノ粒子を導体化した皮膜の抵抗值は, $4 \mu \Omega \cdot \mathrm{cm}$ であり， めっきやスパッタで生成した皮膜と比較すると, 抵抗值が大 きくなる。本検討では，平均粒径 $70 \mathrm{~nm}$ の $\mathrm{Cu}$ ナノ粒子を利 用しており，焼成時に有機物や残存溶媒が気化，分解し皮膜 外に抜ける経路が必要となる。基材の耐熱温度付近もしくは 瞬間的に焼成しているため，焼成時に $\mathrm{Cu}$ ナノ粒子は完全に 融解しておらず，粒子表面の $\mathrm{Cu}$ 原子が接触する $\mathrm{Cu}$ ナノ粒 子との界面に拡散し, $\mathrm{Cu}$ ナノ粒子同士がネッキングし, 空 孔を残して焼結しているため, 抵抗值が上昇する。

\section{3. セミアディティブ回路形成プロセス}

焼成した $\mathrm{Cu}$ ナノインクをめっきのシード層として利用す

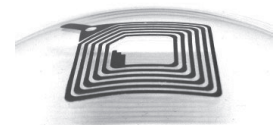

図 1 ガラス曲面上への SP 印刷

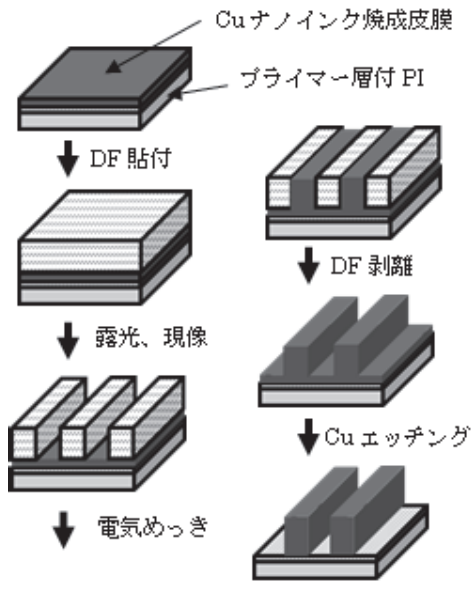

図 2 SAP プロセスの概略

る新たなセミアディティブプロセスの概略を図 2 に示す。密 着層を塗布したポリイミド基材上に $\mathrm{Cu}$ ナノインクを塗布し, 前項に記した光焼成プロセスにより約 $0.6 \mu \mathrm{m}$ の $\mathrm{Cu}$ ナノイ ンク焼成皮膜のシード層を形成する。次に，シード層上にド ライフィルム $(\mathrm{DF})$ フォトレジストを貼付, 露光, 現像する。 現像後のサンプル上に, 電気銅めっきで増膜後, DF を剥離し, 全面 $\mathrm{Cu}$ エッチングしてシード層を除去し, $\mathrm{Cu}$ 回路を形成 する。本プロセスでは, 大型の真空装置を必要とせず，イン ク塗布から回路形成まで, Roll to Roll プロセスが適用できる ため，低コストで回路基板の製造が可能である。ここで，得 られたサンプルの $150{ }^{\circ} \mathrm{C}$ 高温負荷試験をおこなった。比較と して，一般的な接着層を含む 3 層フレキシブル基板 (FCCL) についても同様の試験をおこなった。試験前の剥離強度は, $\mathrm{Cu}$ ナノインクをシード層とするサンプルと FCCL でほぼ同 様の約 $1.2 \mathrm{~N} / \mathrm{mm}$ であった。FCCL は，150 ${ }^{\circ} \mathrm{C}$ で時間が経過 するに従い，剥離強度が低下し，500 hr. で $0.31 \mathrm{~N} / \mathrm{mm}$ まで 低下した。一方，本プロセスにより作成したサンプルでは， $500 \mathrm{hr}$. 試験後も $1.07 \mathrm{~N} / \mathrm{mm}$ の剥離強度を維持した。本プロ セスは, 液晶ポリマーなどの直接めっきが難しい基材へも密 着性の良い回路形成が可能である。

\section{4. おわりに}

$\mathrm{Cu}$ ナノ粒子を利用した様々な回路形成方法について紹介 した。 $\mathrm{Cu}$ ナノ粒子から得られた $\mathrm{Cu}$ 導体皮膜は，バルク $\mathrm{Cu}$ の 2 倍程度であり, 回路形成用途として適用可能である。ま た，めっきのシード層として利用することにより，高温負荷 試験後も基材と良好な密着性を有する回路形成が可能である。

\section{文献}

1 ）菅沼克昭, 能木雅也 ; 表面技術, 61, 12 (2010)

2 ) 有村英俊; 表面技術, 64, 11 (2013).

3 ) 南原 聡, 川戸祐一, 有村英俊; エレクトロニクス実装学会誌, 21, 6 (2018).

（石原ケミカル(株) 有村 英俊） 